\title{
Labouring Transformations of Amphibious Monsters: Exploring Early Modern Globalization, Diversity, and Shifting Clusters of Labour Relations in the Context of the Dutch East India Company (1600-1800)*
}

\author{
Matthias VAN Rossum \\ International Institute of Social History \\ Cruquiusweg 31, IOI9 AT Amsterdam, The Netherlands
}

E-mail: mvr@iisg.nl

\begin{abstract}
Early modern globalization depended on labour-intensive production and transport of global commodities. Throughout the Dutch Empire of the seventeenth and eighteenth centuries labour was mobilized through a variety of different labour relations (especially casual, contract, slave, and corvée labour). The mobilization of these workers often entailed movements over short, but more often long, distances. Port cities were crucial nodal points connecting various sites of production and circuits of distribution. Furthermore, these ports were themselves also important working environments (ranging from transport and storage, to production and security). As a result, workers from various regional, social, and cultural backgrounds worked in the same environments and were confronted with each other - as well as with the legal and disciplining regimes of early modern urban and corporate authorities. This article studies the development of labour relations in the port work of the Dutch Asian empire, looking at the mobilization and control of labour for dock work (loading and unloading of ships) and transport in its urban surroundings. It will analyse and compare the development of the need for labour, the employment of different sets of labour relations, and the mechanisms of control that developed from it. As the largest trading company active in Asia (up to the 1750s), the case of the Dutch East India Company (VOC) is crucial in understanding the impact of early imperial and capitalist development in changing global social and labour relations.
\end{abstract}

In 1734, the "indigo maker Christiaan Frederik Canselaar was sent to Ambon accompanied by four Javanese" for the purpose of disseminating

\footnotetext{
* This article draws on research conducted as part of the "Between Local Debts and Global Markets: Explaining Slavery in South and Southeast Asia, I600-1800" project (Matthias van Rossum, NWO Veni Grant, 2016-2019) and the "Resilient Diversity: The Governance of Racial and Religious Plurality in the Dutch Empire, I600-I800” project (Cátia Antunes, Ulbe Bosma, Karwan Fatah-Black, and Matthias van Rossum, NWO Vrije Competitie Grant, 2017$202 \mathrm{I})$.
} 
the production of indigo, one of the global commodities crucial to early modern globalization and European expansion. ${ }^{\mathrm{I}}$ The Javanese were contracted for five rijksdaalder per month. ${ }^{2}$ The population of Ambon was mobilized for labour by other means. Reporting to the authorities in the Dutch Republic, the Generale Missiven noted that "the population of [the island] Amblau was exempted from service on Buru on condition that they keep to their promise to plant indigo themselves". 3 The dienst (service) referred to here was the coerced corvée labour that local subjects had to perform for the Dutch East India Company (VOC), which was now exchanged for the production of indigo. This interest in the management of cash-crop production by the VOC was no coincidence. The report continues with explicit rationales, pointing out that "the ground of [the neighbouring island] Hitu does not seem very promising for indigo cultivation", while at the same the "cultivation of coffee was not encouraged because Java was already delivering enough". ${ }^{4}$

The historical perspective on early modern world trade and European expansion has been strongly influenced by the notion of itinerario, which can be translated as a guide for travelling or for finding one's route, and is derived from the Latin verb itineror, to travel. The landmark account of the richness of late-sixteenth-century Asia, published under this title by Jan Huygen van Linschoten in I 596, had already systematically described ports, commodities, and trading opportunities. ${ }^{5}$ The influence of this perspective is still felt in the process of early globalization, which is to a large extent understood as trade-driven maritime European expansion, captured with concepts such as merchant empires and merchant capitalism. ${ }^{6}$ The VOC is an interesting and crucial example of this, with an extensive historiography describing it as a trading company or a merchant warrior. ${ }^{7}$ The conceptualization of the VOC as a merchant has been strengthened by the

I. W.P. Coolhaas et al., Generale Missiven van Gouverneurs-Generaal en Raden aan Heren XVII der Verenigde Oostindische Compagnie, I4 vols (The Hague, I960-2007), IX, p. 548.

2. Or I 2.5 guilders, roughly an average monthly salary for a Company servant.

3. "De bevolking van Amblau is vrijgesteld van de dienst op Buru mits men zich aan zijn belofte zelf indigo aan te planten houdt." Generale Missiven, IX, p. 548.

4. Ibid.

5. Jan Huyghen van Linschoten, Itinerario, voyage ofte schipvaert van Jan Huygen van Linschoten, naer Oost ofte Portugaels Indien, I579-I592 (Amsterdam, I 596).

6. For example, N. Steensgaard, The Asian Trade Revolution of the Seventeenth Century (Chicago, IL, I973); J.D. Tracy (ed.), The Rise of Merchant Empires: Long-Distance Trade in the Early Modern World, 1350-I750 (Cambridge, I990), pp. I02-I 52.

7. G.D. Winius and M.P.M. Vink, The Merchant-Warrior Pacified: The VOC (The Dutch East India Company) and its Changing Political Economy in India (Oxford, 1995); F.S. Gaastra, Geschiedenis van de VOC. Opkomst, Bloei en Ondergang (Zutphen, 2009). 
dominant perspective of departure (and return). For long, many studies focused on the ships setting sail to Asia from the Dutch Republic, the sailors departing, and the trading goods brought back. ${ }^{8}$

Only more recently have the importance of the Asian or "overseas" sides of the organization of the VOC, its social, economic, and political dimensions, received more attention. Several studies opened up "Asian" perspectives on the Dutch East India Company, rather than solely the perspective of "intercontinental" connections, pointing out that the trade within Asia was crucial to the Company. ${ }^{9}$ With regard to the VOC's workforce, it has been stressed that the VOC employed most of its personnel in Asia, and that roughly half of the workforce was Asian. ${ }^{10}$ The VOC actually employed most of its ships in intra-Asiatic shipping and manned those ships with multicultural European and Asian crews. ${ }^{\text {I }}$ Despite this shift, the perspective of the merchant has remained strong, even dominant. Els Jacobs, for example, admits that "European trading companies possessed the power and means to enforce the essential native cooperation through violence", but nevertheless

8. This argument has been preluded in M. van Rossum, Werkers van de wereld. Globalisering, arbeid en interculturele ontmoetingen tussen Aziatische en Europese zeelieden in dienst van de VOC, I600-I 800 (Hilversum, 20I4), and some of its implications have been explored in idem, "Sampans, hout en slaven. De overzeese infrastructuur voor scheepsbouw en -onderhoud van de Verenigde Oost-Indische Compagnie in Zuid- en Zuidoost-Azië", Tijdschrift voor Zeegeschiedenis, 36:2 (2017), pp. 3-2 I [translated into English as "Building Maritime Empire: Shipbuilding and Networks of Coercion under the Verenigde Oost-Indische Compagnie (VOC) in South and Southeast Asia", International Journal of Maritime History (submitted). For examples of this, see J.K. Beers and C. Bakker, Westfriezen naar de Oost. De kamers der VOC te Hoorn en Enkhuizen en hun recruteringsgebied, I700-I800 (Schagen, I990); J.R. Bruijn, F.S. Gaastra, and I. Schöffer, Dutch-Asiatic Shipping in the I7th and I8th Centuries (The Hague, 1979-1987); J.R. Bruijn and F.S. Gaastra (eds), Ships, Sailors and Spices: East India Companies and Their Shipping in the I6th, I7th and I8th Centuries (Amsterdam, 1993); D. van den Heuvel, "Bij uijtlandigheijt van haar man". Echtgenotes van VOC-zeelieden, aangemonsterd voor de kamer Enkhuizen (I700-I750) (Amsterdam, 2005); W.M. Jansen and P.A. de Wilde, "Het probleem van de schaarste aan zeevarenden in de achttiende eeuw" (MA thesis, University of Leiden, I970); H. Ketting, Leven, werk en rebellie aan boord van Oost-Indiëvaarders (I595-I650) (Amsterdam, 2002); J. Parmentier, Uitgevaren voor de Kamer Zeeland (Zutphen, 2006); K.L. van Schouwenburg, "Het personeel op de schepen van de Kamer Delft der VOC in de eerste helft der i8e eeuw", Tijdschrift voor Zeegeschiedenis, 7 (1988), pp. 76-93; K.L. van Schouwenburg, "Het personeel op de schepen van de Kamer Delft der VOC in de tweede helft der ise eeuw", Tijdschrift voor Zeegeschiedenis, 8 (1989), pp. 179-2 I 8.

9. Gaastra, Geschiedenis van de VOC; E. Jacobs, Koopman in Aziё (Zutphen, 2000); J.R. Bruijn, "De personeelsbehoefte van de VOC overzee en aan boord, bezien in Aziatisch en Nederlands perspectief”, Bijdragen en Mededelingen betreffende de Geschiedenis der Nederlanden, 91:2 (1976), pp. 21 8-248.

I0. Jan Lucassen, "A Multinational and its Labor Force: The Dutch East India Company, I 5951795", International Labor and Working-Class History, 66:2 (2004), pp. I 2-39.

I I. Van Rossum, Werkers van de wereld. 
argues that a survey "of all settlements makes quite clear that the Company in Asia really operated as a merchant". ${ }^{12}$ This article argues there is a need to break with such perspectives, and it aims to explore the implications of doing so.

In recent decades, research has made it increasingly clear that the VOC cannot be characterized solely as a merchant organization, and that the functions of the Company extended to those of continuous warfare, government responsibilities, and even interfering in and organizing agricultural production. Recent studies remind us that the Company acted with different degrees of sovereignty and took on a pivotal role in regulating regimes of slavery, administering the slave trade and enforcing corvée duties. ${ }^{\mathrm{I}}$ The VOC operated not only at sea and in ports; it was a more amphibious monster, acting not only as "merchant", but also taking on multiple roles as "ruler", "soldier", and "producer".

This article explores the way the Dutch East India Company operated in employing and developing labour regimes in both production and transport work throughout its Asian empire. It does so as a case study to understand early global capitalism through the lens of the mobilization and control of labour employed for the production and transportation of several key global trading commodities of this period, including indigo, but also cinnamon, pepper, sugar, and coffee. It will analyse and compare the development of the need for labour, the employment of different sets of labour relations, and the mechanisms of control and regulation of diversity that developed from this in different parts of the empire of the VOC. The implications of this exercise range wider than merely providing a different account of the VOC but hold important clues for advancing global historical debates on shifts in labour relations, as well as on the nature and impact of early empire. It indicates that the reach of early modern (merchant) capital extended well beyond maritime trade and port economies, but also aimed to control and shape the South and South East Asian countryside, significantly impacting shifts in labour regimes and social relations in regions that were drawn into the spheres of direct and indirect influence of early empires.

I 2. Jacobs, Koopman in Azië, "De rondreis langs alle vestigingen maakt goed duidelijk dat de Compagnie in Azië werkelijk als een koopman opereerde".

I 3. G. Knaap, “De 'core business' van de VOC: Markt, macht en mentaliteit vanuit overzees perspectief”, inaugural lecture, University of Utrecht, ro November 2014; M. van Rossum, Kleurrijke tragiek. De geschiedenis van slavernij in Azië onder de VOC (Hilversum, 2015); Linda Mbeki and Matthias van Rossum, "Private Slave Trade in the Dutch Indian Ocean World: A Study into the Networks and Backgrounds of the Slavers and the Enslaved in South Asia and South Africa", Slavery E Abolition, 38:1 (2017), pp. 95-1 16; Jan Breman, Mobilizing Labour for the Global Coffee Market: Profits from an Unfree Work Regime in Colonial Java (Amsterdam, 201 5), available at: https://www.oapen.org/search?identifier= 597440; last accessed is February 2019. 


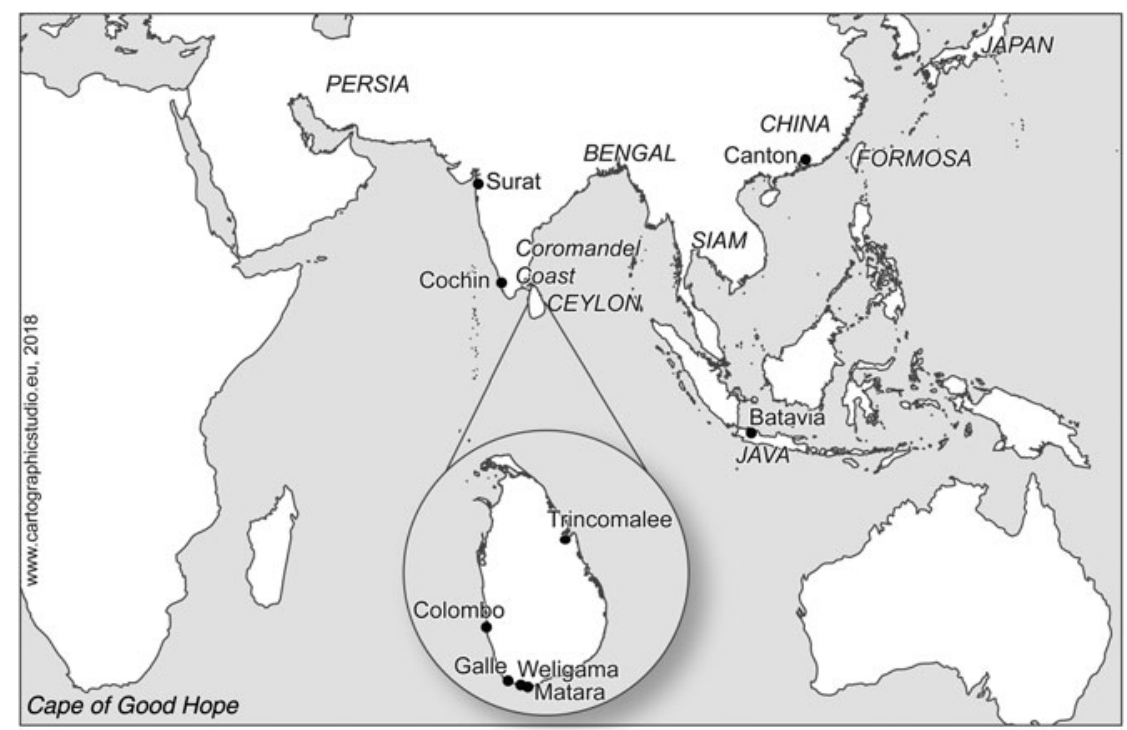

Figure I. Selected places in the Dutch East India Company Empire that are mentioned in this article in relation to forced labour relations or transformations in labour relations.

\section{EXPLORING GLOBALIZATION, CAPITALISM, AND IMPACT}

As the largest company active in Asia (up to the 1750s), the case of the VOC is key to understanding the impact of early imperial and capitalist development in changing global social and labour relations. The proponents of the perspective of early modern globalization and capitalist expansion as being characterized predominantly as trade or merchant phenomena have raised doubts concerning the links, or causal effects, of colonialism. Jan de Vries, for example, challenges "the argument that intercontinental trade, through its differential impact on the location of commercial life, forced changes in political institutions that were favourable to long-term economic growth" in Europe. De Vries concludes: "When all is said and done, we are presented with two simultaneous developments - the establishment and development of a global maritime trading system under western European direction and the divergent growth of the western European economies - and are asked to believe that a causal link exists connecting the first to the second". ${ }^{14}$

The case of the Dutch East India Company is an important reminder that such links remain insufficiently explored up to this day and should also be investigated in the reverse direction. Given that early modern globalization 
was dependent not only on the highly labour-intensive modes of maritime transportation but also on labour-intensive, often rural production processes of the global commodities involved, the best places to study the effects of global trade are the spheres of production and transport outside Europe. Throughout the European empires that underpinned early modern global trade, the pressure to procure and allocate labour in effective ways was extremely high. Therefore, the port cities studied in this Special Issue were not just crucial nodal points connecting various sites of production and circuits of distribution, they were also simultaneously employed as the centres of empire, from which coercive imperial activities radiated that underpinned the global commodity chains from transport and storage, to production and security.

The history of labour mobilization in the Dutch East India Company empire is part of this larger story in which, throughout the Dutch and other empires of the seventeenth and eighteenth centuries, labour was mobilized through a variety of different, but often coercive, labour regimes, based most notably on contracts, slavery, and corvée. The mobilization of these workers often entailed more or less controlled or forced mobility over sometimes short, and more often long, distances. As a result, workers from various regional, social, and cultural backgrounds came to work in the same environments in these ports and their hinterlands. There they were confronted with each other within the framework of legal and disciplining regimes of early modern imperial state-corporate and private authorities. In the case of the European companies in Asia, all this occurred in the context of a highly developed world, with strong states in South, South-East and especially East Asia, and by complex economic systems marked by markets, monetization, and a high diversity of labour relations, ranging from casual wage, contract, slave, and corvée labour.

The labour regimes of ports and hinterlands - the regimes of waterfronts, cities, and rural places of agricultural production - were not separated, but deeply connected. Entanglements between the systems of labour mobilization came about not only through the flows of commodities and the chains of imperial command, but especially through the exchange, interaction, and overlap of labour systems employed and refined by global organizations such as the Dutch East India Company. The active engagement and experimenting of the VOC with the refinement and transplantation of labour regimes indicates that we should consider the deeper impact of the transformations set in motion by the socio-economic and political regimes behind the early modern trade connections. Whereas the study of globalization has been largely connection-centred, cultural historical studies such as that by $\mathrm{McC}$ ants remind us that such early connections may have been restricted to "small luxuries" but nevertheless led to "mass consumption". Is Taking on 
board these insights into the field of social and labour history means we should consider much more systematically how the production, transport, and control of such "small" luxuries actually demanded massive mobilization of labour globally. The labour-intensive character of early global contacts affected a multiplicity of aspects of people's lives - work, migration, social and political relations, policing, and more - and fuelled experiments with labour regimes - in maritime hubs and in agricultural hinterlands. The impact and transformative effects of this remain to be scrutinized much more systematically in global labour history as a field.

A consideration of the role of the changes set in motion by globally integrating commodity chains under war capitalism, like that of Sven Beckert in his study of global capitalism through the history of cotton, is a crucial step forward. Emphasizing the role of conquest and coercion in early modern capitalism, Beckert also argues, however, that the expansion of merchant capital, especially in Asia, occurred "largely without exploding older social structures" until the late eighteenth century. ${ }^{16}$ This might indeed be the case for commodities like cotton, in which strong networks of producers and merchants were able to maintain rather high degrees of control, but it seems to have played out differently for other key global commodities. We should reconsider, therefore, whether the characterization of war capitalism accounts sufficiently for the nature and scope of social and labour transformations already set in motion by early modern imperial and capitalist expansion. The expansion of world trade resulting from European expansion in the quest for global commodities in Asia, such as nutmeg, cinnamon, and pepper, but also indigo, sugar, and coffee, seemed to have important transformative effects.

This insight is important especially in the light of recent historiographical turns in global labour history, which have indicated that many forms of labour relations, ranging from free to unfree, existed and continued to exist throughout history. Early modern (and later) global and capitalist expansions were intimately linked to unfreedom and coercive labour relations. ${ }^{17}$ Since the search for linear shifts from unfree to free labour relations has been abandoned, it is increasingly recognized that multiple labour relations not only existed alongside each other, but also in relation to each other. This implies we should start to think about transformations in labour regimes from the notion of clusters of labour relations. Rather than the occurrence and development of single labour relations, it is the specific cluster (or "combinations") of labour relations as they occur in a specific historical context that

I6. S. Beckert, Empire of Cotton: A New History of Global Capitalism (London, 2014), pp. 3$55,22$.

17. A. Stanziani, After Oriental Despotism: Eurasian Growth in a Global Perspective (London, 20I4); Beckert, Empire of Cotton; M. van der Linden and M. Rodríguez García (eds), On Coerced Labor (Leiden, 2016). 
should be understood and explained. This holds equally true for historical transitions in labour regimes - these entail not merely the shift from one labour relation to another, but also shifts of specific combinations or clusters of a set of labour relations to another cluster of labour relations. ${ }^{18}$

The case study of labour relations under the VOC indicates the importance of revising our understanding through such an approach. The VOC employed contract labour, slave labour, corvée labour, and casual wage labour, and actively attempted to manage and transplant labour regimes across different regions. This provides an interesting insight into how the labour-intensive character of early modern globalization motivated the drivers of the early capitalist expansion that supported it (corporations, states) to develop practices for the mobilization of labour that had a deep and lasting impact on a multitude of local societies across the globe. This impact was not limited to the organization and management of labour, and the histories of slavery and coercion, but also - through regimes of control and differentiation - extended into wider spheres of social and cultural relations.

\section{CONQUEST, CORVÉE, AND TRADE - THE DUTCH OVERSEAS MONSTER AT WORK}

As the largest company operating in Asia from the beginning of the seventeenth century until the mid-eighteenth century, the Dutch East India Company provides an interesting and important case. ${ }^{19}$ The Company's activities were not limited to that of trade, but extended to include diplomatic relations, and more importantly to warfare and government responsibilities such as taxes, administration, and justice. Roughly a quarter to a third of the VOC workforce were military personnel. ${ }^{20}$ In 1760 , according to a survey of the political positioning of the VOC by Knaap, the VOC had sovereignty in six regions (Batavia, Java's north-east coast, Banda, Ambon, Ceylon, and the Cape of Good Hope), suzerainty (indirect rule) in twelve regions, and extra-territorial rights in five places (Japan, China, Bengal, Surat, and Persia). ${ }^{2 \mathrm{I}}$

I8. M. van Rossum, “Redirecting Global Labor History?”, in C. Antunes and K. Fatah-Black (eds), Explorations in History and Globalization (London, 2016), pp. 47-62, 52; Matthias van Rossum et al., "Moving the 'Free and Unfree Labour' Debate Forward", ISHA Newsletter, 5:I (2016), pp. I 5-18, I6.

19. Van Rossum, Werkers van de wereld, pp. 70-74.

20. Knaap, “'Core business”, p. I7; M. van Rossum, “Working for the Devil': Desertion in the Eurasian Empire of the VOC", in M. van Rossum and J. Kamp (eds), Desertion in the Early Modern World: A Comparative History (London, 2016), pp. I27-I60, I33.

2 r. Knaap, “'Core business”, pp. I 8-19. In some places categorized under suzerainty, the VOC had stretches of land, such as the Malabar coast, where it owned and leased out lands in the conquest of Paponetty. 
This was part of a system in which the VOC had gained access to global commodities through balancing trade, monopoly claims, and warfare. At the beginning of the seventeenth century, the VOC had secured control over the islands that produced cloves (Ambon, I605), mace, and nutmeg (Banda, I62I) through a series of conquests. After the conquest and destruction of Jacatra (I6I9), the Company built the settlement of Batavia as its main headquarters. From here it pursued the trade in that other important spice, pepper. The VOC would never completely possess the areas producing pepper (Sumatra, Malabar), but, over the course of the seventeenth and eighteenth centuries, it would increase its influence by building up a strong political presence through conquest (Cochin, I663) or establishing suzerainty. Increasingly, the Company was able to enforce contracts for the delivery of pepper for prices below market value. The VOC continued its conquests more to the north of the Indonesian archipelago, where it conquered the important trading hub of Malacca (I64I), and especially Formosa (1622-1663), a crucial link in the trade with China, but also interesting as a site for the production of sugar.

Having established the core of its power, the VOC turned its eyes to the Indian Ocean, where it gained control over coastal Ceylon, the only major area producing cinnamon, in a series of conquests (Galle, I64I; Colombo and Jafnapatnam, 1654-1658). As the Coromandel coast was crucial for obtaining high-quality textiles, which were important trading goods in South East Asia and elsewhere, the VOC established a series of forts and trading offices there, as well as control over several cities. The VOC obtained permission to build a fort in Bengal (Houghly) as a way to secure its position in the trade in saltpetre, opium, and silk. The Cape of Good Hope (I652) had become an important resupply station for shipping between Europe and Asia, and with the expansion of European settlement in the hinterland over time it developed into an agricultural production area. In the meantime, the city of Batavia and its surroundings (ommelanden) developed into one of the major production areas for sugar, which was exported largely to Japan and the Western-Indian Ocean region. In the eighteenth century, coffee and tea would become crucial trading commodities for the European markets. Tea was obtained mainly through direct trade in Canton, but coffee was produced in Java.

Two observations are important for our understanding of early modern globalization. First, although their rapid expansion over the seventeenth and eighteenth centuries may have been an important factor in the acceleration of connections, it was not only European markets driving the demand for the global commodities pursued by companies like the VOC. The trade within Asia was extremely important for the VOC, and was not negligible, even compared to the bulk trade in spices, coffee, and other goods to Europe. Especially sugar (Figure 2) and textiles, but also pepper and other commodities such as opium, were important trading goods for Asian 


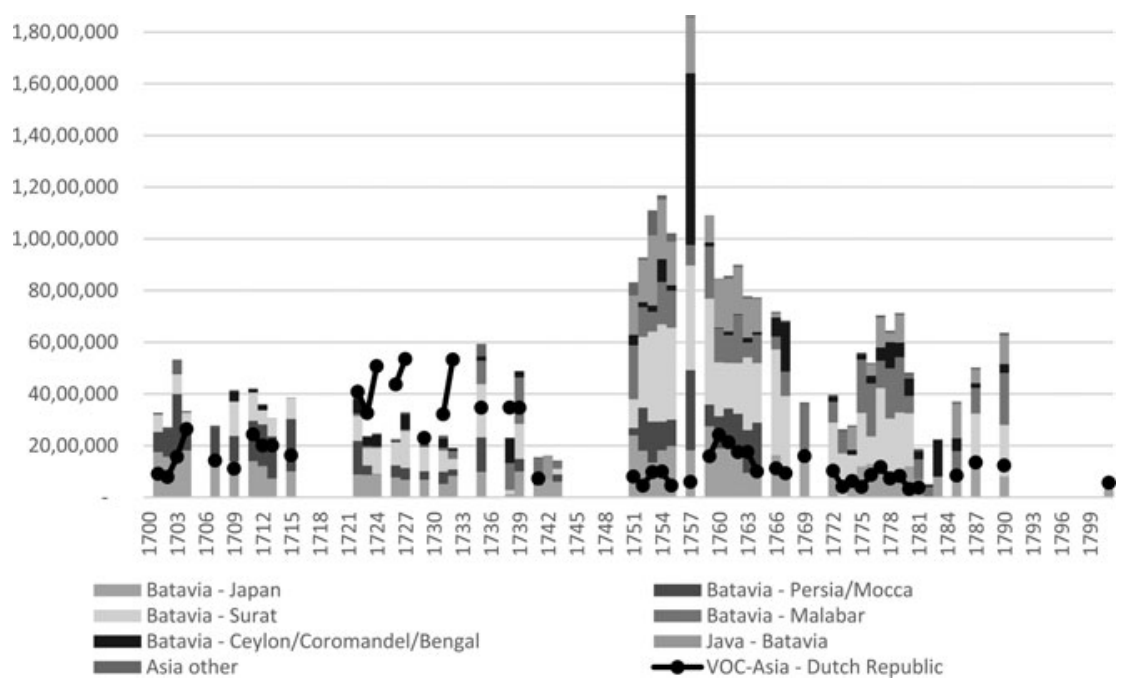

Figure 2. VOC transport of sugar on intra-Asian and intercontinental routes (lbs). ${ }^{22}$ Boekhouder-Generaal Batavia (BGB), available at: http://bgb.huygens.knaw.nl; last accessed; November 2018.

markets. It is important, therefore, to assess the volume of trade not only along the Europe-Asia axis of global connections, but also through longdistance connections in a truly global sense. Asia was not only a production site, it was also a crucial market for several of the global commodities the VOC traded in. Any assessment of the impact of global trade must therefore account for the activities in Asia's long-distance trade. ${ }^{23}$

Second, the VOC was heavily involved in the production of many of its key commodities, directly and indirectly stimulating coercive production regimes. The production of cloves on Ambon, for example, was undertaken by the local inhabitants, but controlled by the VOC through monopoly claims. The population was obliged to sell the entire harvest of cloves to the Company for a fixed price. The VOC prohibited the production of cloves elsewhere and organized annual hongi-tochten (extirpation expeditions) for inspection and extermination. ${ }^{24}$ The thousands of Ambon workers (mainly

22. To avoid double counting resulting from transshipment, the data for the route Batavia-Malabar excludes Malabar-Ceylon, and the data for Batavia-Ceylon/Coromandel/ Bengal excludes Ceylon Republic and Bengal Republic.

23. Cf. De Vries, "The Limits of Globalization in the Early Modern World”, p. 720; J. de Vries, "Connecting Europe and Asia: A Quantitative Analysis of the Cape-Route Trade, I497-I795", in Dennis O. Flynn, Arturo Giráldez, and Richard von Glahn (eds), Global Connections and Monetary History, I470-I 800 (Aldershot, 2003), pp. 46-49, 56-6I. See, for this critique, Van Rossum, Werkers van de wereld, introduction and ch. I.

24. G.J. Knaap, Kruidnagelen en Christenen: de Verenigde Oost-Indische Compagnie en de bevolking van Ambon 1656-1696 (Leiden, 2004); Jacobs, Koopman in Azië. 
rowers) recruited for these hongi-tochten were mobilized through corvée labour services. A similar monopoly system was employed for the Banda Islands, but here production was organized around small plantations (perken). The land was owned by the VOC and leased out to European (and later mestizo) owners, who worked with enslaved labourers. The VOC actively sought Europeans, who would be able to "govern slaves", and also actively sustained the enslaved population, providing slaves for cost price from Timor and elsewhere. ${ }^{25}$

On Ceylon, the VOC profited from a system of corvée labour for the production of cinnamon and various other kinds of work. Different groups of inhabitants were obliged to perform different kinds of labour. The production of cinnamon was organized through the obligation that chialias (caste groups) harvest and deliver cinnamon for the Company. Other groups were obliged to provide military labour (lascarins) or general services, such as transport (koelies). ${ }^{26}$ These were significant obligations. In 1657 , for example, it was reported that the "chaleas from the Seven Corlas [Districts] had delivered approximately 670 bhaer cinnamon of 480 pounds [32 I,600 pounds in total] to the warehouses of Negombo". ${ }^{27}$ The pressures of corvée labour led time and again to resistance from the local population, with recurrent revolts in the periods I736-I737, I744-1747, I757-1762, and $1783-90 .{ }^{28}$ On 28 April I730, several heads of the districts around Colombo and Negombo petitioned the VOC concerning the introduction of (obligated) pepper production, because "the people were burdened with many other Companies services", such as "the planting of Cardamom", the "planting and maintenance of the coffee trees", and the "harvesting and transport of cinnamon". ${ }^{29}$

Whereas cinnamon production would rise to over 700,000 pounds per annum (Figure 3), Ceylonese coffee production did not develop quickly under the VOC, with the harvest not exceeding 67,000 pounds in $1740 .^{30}$ Resistance to new crops seems to have played an important part in this. In a revolt among cinnamon peelers in 1736 , a group of 1,000 protesters attacked the Company's cow barn, refinery, and warehouses and caused damage "to the Company's coffee-garden". ${ }^{3}$ Not much later, it was decided no

25. For example, H.T. Colenbrander, Jan Pietersz Coen: bescheiden omtrent zijn bedrijf in Indië, 7 vols (The Hague, I919-1953), I, pp. 374, 708.

26. See, for example, the instructions for the captain of the cinnamon peelers, "Instructie voor de kapitein van de kaneelschillers”, 2 I June I661, in L. Hovy, Ceylonees Plakkaatboek: Plakkaten en andere wetten uitgevaardigd door het Nederlandse bestuur op Ceylon, 1638-1796, 2 vols (Hilversum, I991), I, no. 64.

27. Generale Missiven, III, p. I69.

28. Hovy, Ceylonees Plakkaatboek, LXIII.

29. Nationaal Archief [hereafter, NA], Archive of the VOC [VOC], archive number 1.04.02, inventory number 8952, fos 79I-793 [scan 819-82I].

30. Generale Missiven, X, p. 442 .

3. Generale Missiven, IX, p. 732. 


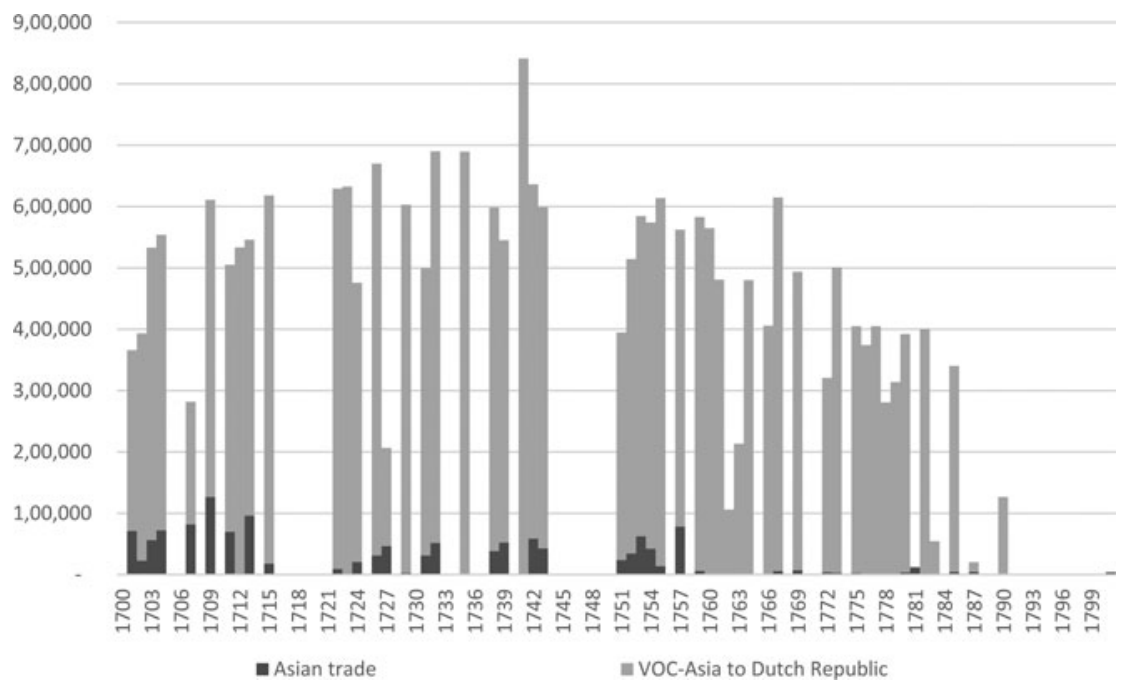

Figure 3. VOC transport of cinnamon on intra-Asian and intercontinental routes (lbs). ${ }^{32}$ $B G B$, available at: http://bgb.huygens.knaw.nl; last accessed s November 2018.

longer to encourage "coffee cultivation" on Ceylon and to try to promote "in the kindest manner" the production of pepper instead by obligating community heads to deliver specific amounts to the Company. ${ }^{33}$ The production of coffee on Java was more successful, with harvests reaching almost six million pounds as early as the mid-I730s, peaking at almost eleven million pounds in the 1790 s (Figure 4).${ }^{34}$ Introduced on Java in the first decade of the eighteenth century, the production of coffee was brought under the monopoly system in 1723 , making it illegal to sell coffee produced on Java to anyone other than the VOC, and it became an obligated corvée service in the following years. The VOC's role in coffee production was significant the residents and regents in these parts of Java fell directly under VOC rule. ${ }^{35}$

The active role of the VOC in the production of its trade commodities becomes clear also from the continuous search to improve and develop the cultivation of different "cash crops" (cultures) in its empire, with the VOC experimenting with coffee and pepper on Ceylon, and with indigo and silk

32. Data are based on all cinnamon cargoes recorded in the Boekhouder-Generaal Batavia, expressed in pounds and balen; the weight of a baal is estimated at 55 pounds. The Asian trade includes all cargo shipments on Asian routes, except the Ceylon-Batavia route (which was mainly for transshipment to the Dutch Republic); the intercontinental trade is included through all cargo shipments to the Dutch Republic.

33. Generale Missiven, X, pp. 207, 442.

34. Breman, Mobilizing Labour, p. 83.

35. Ibid., pp. $75-77,2$ I. 


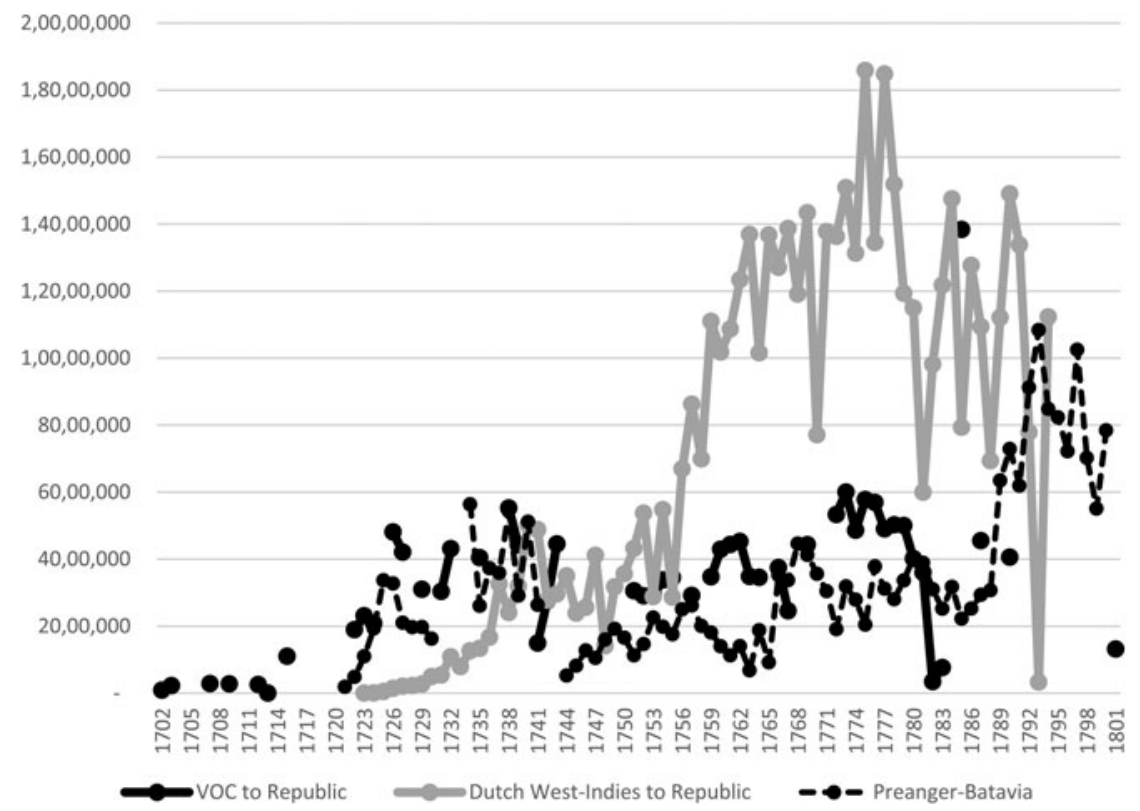

Figure 4. Coffee transport from Dutch East Indies and Dutch West Indies to the Dutch Republic, including deliveries of obligated coffee production in Batavia (lbs).

$B G B$, available at: http://bgb.huygens.knaw.nl; last accessed s November 2018.

on Java, for instance. Corvée labour played an important role in this search. In this context, the population of the island of Amblau were "exempted from service on Buru on condition that they kept their promise to plant indigo". ${ }^{36}$ For those inhabitants who went to the neighbouring island of Buru to work in the indigo culture, the Company paid "one stuiver and a pound of rice daily, being the same as what the quaartslieden [corvée labourers] receive in that province". ${ }^{37}$

In some cases, mainly textile, sugar, and pepper, there were also exceptions to the direct role of the VOC in the production regimes of the main global commodities. In the case of pepper, the VOC tried to increase its influence by putting political pressure on local rulers in places like Bantam and Palembang. In the case of sugar, the VOC actively governed the Batavian ommelanden where its production took place. For both products, coerced labour played an important role. Slaves seem to have been employed in the native pepper fields on Sumatra, but also in the sugar fields, sugar mills, and refineries owned by mainly Chinese and European entrepreneurs in 
the Batavian ommelanden. As roughly one third of the population of Batavia and the ommelanden consisted of slaves, the VOC actively regulated the institution of slavery as well as the slave trade. ${ }^{38}$

\section{GLOBAL TRADE AND THE DEMAND FOR LABOUR}

It was not only the production of early modern global commodities that required large numbers of workers. The transport of the many trade goods from the hinterlands to ports and on to ships was also highly labour intensive, and demanded large amounts of physical labour - carrying, lifting, towing, rowing. This work was not without skill but required organization and planning. Skill was vital in dealing with cargoes during transfers, loading chests into small vessels without damaging the cargo, for example. Even more importantly, loading a ship in the right way was crucial not only for the amount of cargo it could carry, but even more so for the sailing capacities of the ship. In 1717 , for example, Gerrit van der Zijden, the equipage master of Batavia, responded to the accusation that two ships had not been loaded well, explaining that had the saltpetre and iron nails not been placed in this manner the ships "would have been barely able to cross the sea". 39

An illustrative example of the massive work entailed is provided by historian Lodewijk Wagenaar in his study of the port city of Galle. He describes the laborious task of loading (and unloading) vessels through the examples of two ships, De Drie Papegaaien and Leimuiden, destined for a return voyage to the Dutch Republic. The ships would transport almost I,200 chests (kisten) of Javanese coffee and $\mathrm{I} 32$ chests of Ceylon coffee, each weighing 250 pounds. Another 160,000 pounds of cinnamon was brought on board, distributed over some 1,000 bales. Some 30,000 pounds of tin and over I 00,000 pounds of coral stone were packed in bags or chests. The South Indian cloth was bound together in I,000 packages and the cloth from Surat in some I 20 packages, each weighing some I45 pounds. The most important part of the cargo was 336 tons of Malabar and Ceylon pepper, transported in thousands of jute bags. The cargo was distributed over an estimated total of 14,000 bags, bales, packages, and chests.

To an important extent, the geography of hinterlands and ports shaped the work and the demand for labour. Throughout the early modern period, the large seagoing ships needed to be anchored just offshore. This meant that the handling of cargoes was divided into several stages (from warehouse to dock, to small vessel, to ship) and cargoes needed to be rowed or sailed in small vessels from docks, through rivers or even across the surf. In some places, like Batavia and Siam, the VOC located warehouses on islands. In other

38. Van Rossum, Kleurrijke Tragiek.

39. NA, Collectie Brugmans, I.IO.I3, inv. I68, no. 3. 
places, warehouses remained in the city, near loading docks, like the moelje in Galle. This meant that here "the chests needed to be brought downstairs from the first floor of the large storehouse, through the gate and on to the pier, then into one of the small vessels used for loading and unloading, and into the bay to the seagoing ships, in order finally to be stowed in the ships' hold". ${ }^{\circ}$

The volume of the trade flows thus becomes not only an indicator of the thickness of global connections, but also (and especially) of the massive labour demands in the environments of production and transportation. In the second half of the seventeenth century, the VOC shipped around four million pounds of pepper and half a million pounds of nutmeg and cinnamon to the Dutch Republic annually. ${ }^{41}$ In the eighteenth century, the VOC exported products in even larger quantities, for example large amounts of pepper (some six to ten million pounds), sugar (from four to almost twelve million pounds around the middle of the century), and coffee (from four to six million pounds, to over ten million pounds towards the end of the century) (Figures 2-5).

The workforce employed by the VOC grew along with the expansion of empire and trade. The number of workers directly employed by the Company increased from approximately I 5,000 in 1625 to around 42,000 in the late 1680 s, peaking at 57,000 in the mid-eighteenth century. ${ }^{42}$ Most of them were either contract labourers, especially European and Asian sailors, soldiers, and artisans, or slaves, bought or hired to work in the service of the Company. These estimates exclude the layer of workers drawn into Company service in other ways, especially populations living in Company-subjected territories, who were obliged to perform corvée services. Good surveys of the populations and obligated corvée labour in the VOC empire are lacking, but some sense of scale can be derived from illustrative examples. In the coastal districts of Ceylon, for example, the VOC ruled over an estimated population of almost 280,000 by the late seventeenth century. ${ }^{43}$ The population under Company authority on the Ambonese islands in the 1690 s has been estimated at almost 64,000 , all of whom could potentially be drafted for a total of more than two million days of work. ${ }^{44}$

40. L. Wagenaar, Galle, VOC-vestiging in Ceylon. Beschrijving van een koloniale samenleving aan de vooravond van de Singalese opstand tegen het Nederlandse gezag, I760 (Amsterdam, I994), pp. I $25-\mathrm{I} 26$.

4I. Jacobs, Koopman in Azië, p. 5 I.

42. Lucassen, "A Multinational and its Labor Force", pp. I2-39, I 5; revised in Van Rossum, "Working for the Devil'”, p. I33.

43. P. de Zwart, "Labour Relations in Ceylon in the Late Seventeenth Century", paper supplement to "Ceylon 1650" database, part of the Global Collaboratory on the History of Labour Relations I 500-2000 (International Institute of Social History).

44. Knaap, Kruidnagelen, pp. 139, 199. Knaap indicates that a small part of this was drafted yearly for the hongi and court services (bofdiensten). 


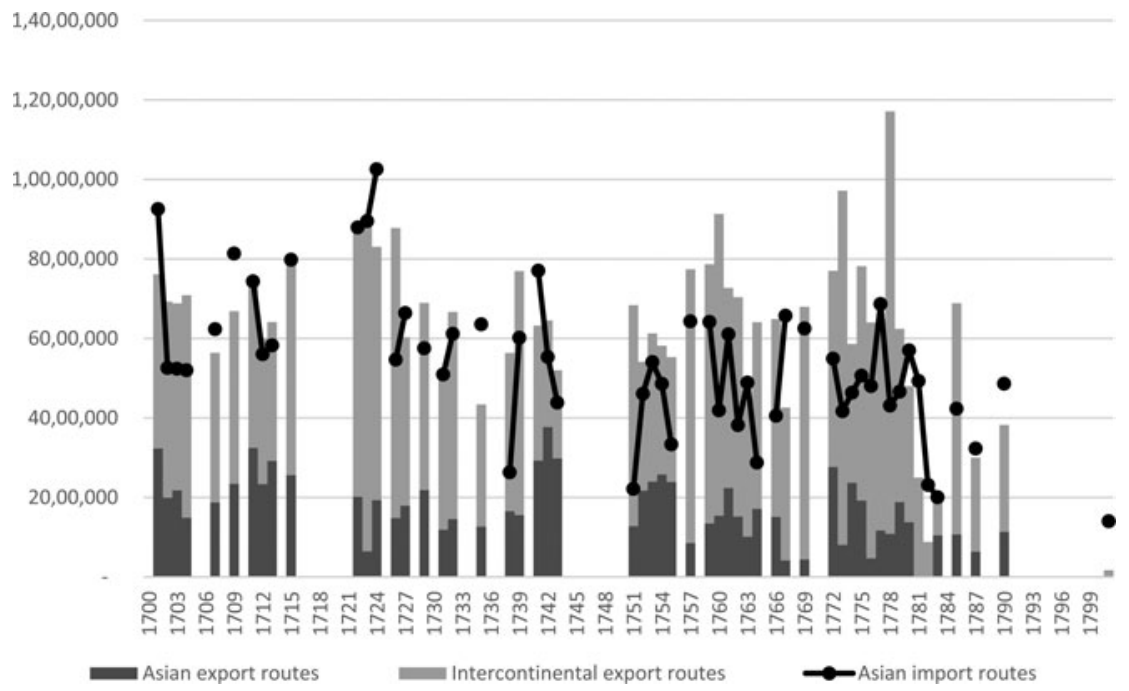

Figure 5. VOC transport of pepper on intra-Asian and intercontinental routes (lbs). ${ }^{45}$ BGB: http://bgb.huygens.knaw.nl; last accessed ; November 2018.

\section{MOBILIZING LABOUR, MANAGING DIVERSITY}

The VOC empire revolved around the organization and control of production and transportation in ports and hinterlands. These environments were not isolated, but strongly related. The circulation of goods or the mobility of people, of course, brought about material connections between ports and their urban and rural hinterlands. Much stronger ties came about, however, through the structures of labour mobilization and control, which were organized for production and transport by the VOC in similar and interrelated ways. The ways in which labour was mobilized in specific settings was not merely a function of geography, production relations, or the location of working environments within the larger socio-political (VOC) system. The VOC actively organized the mobilization of labour around the adaptation, creation, and nurturing of the binding mechanisms engrained in contract, slavery, and corvée; in physical and administrative boundaries; and in legal and socio-ethnic divisions. Although the mechanisms of different patterns

45. Data are based on the total pepper cargoes in the Boekhouder-Generaal Batavia provided in pounds. With a total of $644,356,437$ pounds of pepper accounted for, this excludes 28,270 bags of pepper, 3,384 pikol of pepper, and 2,36 I bahar of pepper. The Asian import routes are included as all cargo shipments on Asian routes to one of the transshipment harbours for Asian and intercontinental destinations (Batavia, Ceylon, and the Cape of Good Hope); Asian export routes are included through all other cargo shipments on Asian routes (either directly from pepperproduction areas, or from the transshipment harbours); the intercontinental export routes are included through all cargo shipments to the Dutch Republic. 
of labour exploitation, control, and coercion could, at times, result in very similar workers' experiences, their effectiveness lay especially in their differentiating effects, increasingly segmenting and tying down workforces.

The case of transport labour in ports and their hinterlands in different parts of the VOC empire is illustrative. In the metropole of Batavia, ships were loaded and unloaded by contract workers (both Europeans and Asians), slaves (Asians), and casual wage workers (Asians). The port of Batavia was a bewildering world of work places, mostly accessible by small rowing and sailing vessels, lying along rivers and canals in Batavia or on nearby islands in the Bay of Batavia. The storehouses were located along the city walls, near canals. The ships wharf was located on the island Onrust and the equipage wharf was located along Batavia's Ciliwung river. Several crucial work sites were located on other islands, such as Edam (rope factory) and Kuyper (ships' repair works). The ocean-going ships of the VOC needed to be anchored some hundred metres offshore as they could not enter the river. The ocean-going ships were loaded and unloaded by small vessels, which could be sailed or rowed from the river to the ships, and back, but needed to be rowed or towed upriver into Batavia. ${ }^{46}$

As Batavia was the main place of arrival for incoming new European personnel, there was always an important reservoir of contract workers, especially sailors, who could be employed in loading and unloading vessels. Being at the end of long intercontinental voyages, however, crews were severely weakened. Ill sailors were immediately placed in the hospital, while soldiers would later be stationed in the military quarters on land rather than remain on board the anchored vessels. In port work, newly arrived sailors were employed alongside Company workers and local workers. They were very visible, not so much owing to their skills as to their behaviour (and inexperience with the climate). Local Chinese port workers distinguished between "orang lama" - old people - and "orang beharu" - new people - who would still have a fairly white skin and would get terribly sunburnt while loading and unloading the ships in Batavia. ${ }^{47}$

From the early seventeenth century onwards, port work in Batavia was done by Company sailors, slaves, and casual local Chinese wage labourers. In 1632, it was decided to employ more slaves and sailors in order to cut back on the cost of hiring Chinese workers. ${ }^{48}$ By the mid-seventeenth century, however, the loading and unloading of vessels was still done by Chinese workers alongside the European sailors and soldiers stationed on

46. Van Rossum, Werkers van de wereld, pp. I53-163.

47. Johann Jacob Merklein, Reise nach Java, Vorder- und Hinter-Indien, China und Japan, I644-I653 (The Hague, I930); Van Rossum, Werkers van de wereld, pp. $250-251$.

48. J.A. van der Chijs, Nederlandsch-Indisch Plakaatboek, I602-I8I I, I7 vols (Batavia and The Hague, i 88 5-1900), I, p. 269. 
the ships before they arrived in Batavia. ${ }^{49}$ With the increasing employment of Indian sailors from the second half of the seventeenth century, however, vital aspects of Batavia port work would become the domain of Indian sailors. In contrast to the local Chinese casual wage workers, these Indian sailors served on multi-annual labour contracts similar to those of European sailors and soldiers. By the mid-eighteenth century, almost 490 "Moorish" (Indian) sailors were registered as employed in Batavia, of whom 272 on the equipage wharf, Ios in rowing and towing vessels upriver ("aan de ploeserscagie"), and thirty-two on one of the flat cargo vessels used in port work ("aan de haijbok"). ${ }^{\circ}$ The Indian sailors employed in Batavian port work were settled in separate quarters near the ploesercasie (boathouse), just under the castle and along the river. ${ }^{5 I}$

In the 1780 , over one hundred Indian sailors were still employed in port work in Batavia, but in the second half of the eighteenth century increasing numbers of Chinese casual wage workers were again hired to complement the labour force of Indian, European, and slave workers. In I 765 , Batavia's opperequipagemeester (head equipage master) argued for the need to "be assisted with Chinese or [other] natives", resulting from the "frequent illnesses of the few available sailors". ${ }^{2}$ Hiring new workers among the local Batavian Chinese community immediately led to complaints about the rising costs of the Chinese hospital, confronted with increasing numbers of injured Chinese port workers going there for treatment and recovery. ${ }^{53}$ In the late 1780 s, in the face of difficulties in bringing in Indian sailors from South Asia as well as in recruiting local workers, the VOC began employing Javanese sailors, hired as contract labourers, on the local small vessels used for port work. Owing to high desertion rates among local Javanese workers, the VOC once again resorted to (more expensive) Chinese and Indian sailors. $^{54}$

Almost from the start, the VOC also relied extensively on the employment of slave labour for the loading and unloading of vessels as well as for the transportation of goods within the city. In the early seventeenth century, unloading the rice brought from ships using small vessels to the storehouses on the east side of Batavia was the work of slaves. ${ }^{55}$ The slave labour employed for the port work comprised slaves owned by the Company,

49. Merklein, Reise nach Java, p. Iof. He mentions: "Zu solcher Arbeit [das Schiff auszuladen] werden fürnehmlich die Chinenser (derer so wol in, als ausser der Stadt Batavien eine überaus grosse Menge, in der Holländer Schutz, und Tribut wohnet) um einen gewissen Lohn; und dann auch die Europeische Schiffleute und Soldaten gebraucht".

50. NA, VOC, 5199.

5. In this, see Van Rossum, Werkers van de wereld, pp. I 53-164.

52. Van der Chijs, Nederlandsch-Indisch Plakaatboek, VIII, pp. 53, I28, 4I6.

53. Ibid., pp. $580-58 \mathrm{I}$.

54. NA, Collectie Brugmans, I7I, f. 99.

55. Generale Missiven, I, p. 422. 
but also slaves hired from private slave owners. With this category of "hired slaves", the boundaries between workers become extremely fluid. The city of Batavia held a very active "coolie" (labour) market of workers performing casual labour, mainly for general work such as (local) transportation of goods or other manual tasks. The word "coolie" here referred to the performance of actual casual wage labour - coolies being hired per day, half day, or even per hour. These casual wage labourers could be both free and enslaved workers, ranging from Mardijkers (local free Asian Christians) or other free inhabitants of Batavia, to slaves being hired out directly by their masters or being sent to hire themselves out to earn "coolie money" (koeliegeld) for their masters. The mobility of these diverse groups of workers was a direct stimulus for the implementation of two types of pass systems directed at both free and enslaved populations. A formal system was imposed by the Company upon Asian sailors and soldiers who left the service of the Company in order to distinguish them from others, especially unfree and Company workers. An informal system was upheld by slave masters, providing written notes to the enslaved when they were sent for work that entailed crossing military posts, or entering or exiting neighbourhoods or parts of the city. Guards would act upon such notices, or the absence of such notices, by permitting slaves to cross or by incarcerating them and sending them back. ${ }^{56}$

Corvée labour played no role in the loading and unloading of vessels in Batavia, but it was crucial for the functioning of the port. Large numbers of corvée labourers were regularly requested from local rulers in order to clear the bed of the sandy Ciliwung river. In I699, for example, the VOC sent a message to the resident of Cheribon noting that "the Princes here have accepted to provide 500 [subjects] to the Company for some time for the clearing of the sandbanks that have grown before the mouth of the river of this city". They announced "that a vessel will be sent off today or tomorrow to summon these men" and warned that they should not delay or wait until "current tasks" had been finished. 57

\section{ADMINISTRATING EXTRACTION, REGULATING MOBILITY}

Along the coast of north-east Java, the VOC increasingly came to rely on a mix of corvée and casual wage labour. In Java, the VOC did not demand or

56. Van Rossum, Kleurrijke tragiek; Hendrik E. Niemeijer, Batavia. Een koloniale samenleving in de 17 de eeuw (Amsterdam, 2005), p. 200. Illustrative is the example of Ontong of Palembang, locked in a trunk for two days and nights at the Moorish Guard in the Chinese campong after being suspected of being absent from house without leave. NA, VOC, 9467, case is .

57. ANRI, file 2519 , fos $245^{-246 .}$ 
administer the corvée labour directly but demanded it from local rulers. At least from the early eighteenth century onwards, the VOC would strike agreements with these rulers on the number of workers to be sent to work for the Company and the compensation to be paid by the VOC to the ruler. In some cases, the ruler would pay modest compensation to workers. Luc Nagtegaal argued that this "forced labour came to be used with increasing frequency" and that "this was not because of any lack of a free labour market", but because it served as an efficient and extremely cheap way of supplying labour. ${ }^{58}$ Indeed, wage labourers could be recruited along the Javanese coast, which was an area with fairly well developed labour markets from early on. ${ }^{59}$ The Company nevertheless pursued a policy increasing the burden and spread of corvée labour systems in Java. ${ }^{60}$

The obligated corvée labourers were employed in the loading of Company ships, which transported especially timber and rice from the Javanese coast. They were also responsible for the transportation of wood from inland areas, along the rivers to the beaches. An agreement with local rulers around Tagal in 1732 obliged the residents of Tagal to "collect the wood rafts from Wallerij, and bring them to the corner of Brebes, where once they arrived there the people of Brebes were to unload the wood rafts and bring them ashore". Furthermore, "when any Company ship was in need of being unloaded or loaded, this was to be done also by the joint Tagal residents". ${ }^{6}$ The daily number of forced corvée workers from Tagal would rise from forty in the I700s, to sixty in the late I7IOs, seventy in the early I720s, and eighty in the 1730 s. In addition, the regents of Pekalongan and Batang would each send some sixty workers daily to Tagal. Similar arrangements were in place along the coast. Nagtegaal states that "in Demak, the inhabitants of eleven villages shared the responsibility for hauling the logs that were floated downstream onto the riverbanks. When a Company ship arrived, these batur tugu or 'log workers' would drag the logs into the sea." ${ }^{22} \mathrm{He}$ argued that there was a division between the employment of corvée labour in regions with stronger rulers, such as Surabaya, Tagal, and Demak, and regions with weaker rulers such as Semarang, where the VOC more generally chose to employ wage labour. These casual wage workers engaged in loading and unloading ships in Semarang would be recruited every morning near the

58. Luc Nagtegaal, Riding the Dutch Tiger: The Dutch East Indies Company and the Northeast Coast of Java, 1680-1743 (Leiden, 1996), pp. 204-206.

59. See, for example, on wage labour: U. Bosma, "Database I650-1900" and "Methodological Paper" (June 20II), The Global Collaboratory on the History of Labour Relations, I 5002000, available at: http://hdl.handle.net/ro622/LCALNW; last accessed 3 November 2018. On sailors: Van Rossum, Werkers van de wereld.

60. Breman, Mobilizing Labour.

6I. NA, VOC, 7822,53 I.

62. Nagtegaal, Riding the Dutch Tiger, pp. 204-206. 
alun-alun (the communal square). Only "at certain peaks, such as when rice had to be loaded on the ships, forced labour was used". ${ }^{63}$ Later in the eighteenth century, the VOC sent Chinese wage workers, recruited in the larger Javanese port cities along with their vessels sailing along the Javanese coast, to work as sjouwers (carriers) and assist in the loading and unloading of the vessels. ${ }^{64}$

In Galle, much of the work in loading and unloading ships was done by the sailors employed by the Company. As return voyages were more heavily manned than intra-Asiatic voyages, sailors must have been more readily available in Galle, which was the second most important port from which return voyages to the Dutch Republic departed. Sailors were, therefore, employed on board the vessels, taking on board the goods and stowing them in the hold. Sailors were also employed on the small vessels sailing between the seagoing vessels and the pier, as well as on the pier itself, for the transport of the goods into the small vessels. ${ }^{65}$

The number of Company workers available was not sufficient, however, for the enormous amounts of goods that needed to be transported from land to shore, and on land, in relatively short periods of time. The VOC therefore employed slaves, who "were used for the loading and unloading of the ships" and were "employed for the work on the fortifications when there was no other work". ${ }^{66}$ The VOC also employed the local population subjected to obligated labour services. In and around Galle, the obligated labour of the "Mooren" - members of South Asian or Muslim communities - was used for "the loading and unloading of the return and other vessels". On 30 September $175 \mathrm{I}$, it was noted in Galle that of a "total of $5 \mathrm{I} 3$ heads" there were 21 3 "dienstbare" [serving] individuals, of whom 72 were "heads who were living in the city of Galle". ${ }^{67}$ The Moors were not the only group obligated to work in the loading and unloading of ships in Ceylonese VOC settlements. In I75 I, the registration of $\mathrm{I}_{3} 8$ "Christians, heathen Chittijs, as well as Paruas, and freed slaves, both of the Honourable Company as private" referred to the employment of "these people in a fashion similar to the Moors" in the loading of vessels and "other services needed by the Company". ${ }^{68}$

63. Ibid.

64. Van Rossum, Werkers van de wereld.

65. Wagenaar, Galle, pp. I23-I 24.

66. Generale Missiven, IV, p. 453.

67. Sri Lanka National Archives [hereafter, SLNA], I/2758, no. I 8.

68. SLNA, I/2758, no. 20. Dutch original: "Christen en heijden Chittijs mitsgaders Paruassen en vrijgelaten slaven, zowel van d"E: Comp: als particuliere"; "ten eijnde zijlieden als de Mooren bij de afladinge en ontlossing der retour en andre scheepen, mitsgaders verder nodige

"s Comp: diensten te konnen werden g"emploijeert". 
In other parts of Ceylon, obligated corvée labour was also employed in loading and unloading goods. Early in February 1760, the transport of chalk near Weligama was delayed because many of the fishermen who were obliged to load the chalk and man the vessels as part of their corvee duties had run away to another district. In March 1760, the obligated corvée labour of fishermen from Matara of the Karawa caste were employed in the transport of wood with rafts. ${ }^{69}$ As late as 1788 , it was reported that the "koelies" employed at the works of the forts of Trincomalee as part of their obligated labour services were used partly in the warehouses and in loading and unloading vessels. ${ }^{70}$ In the second half of the eighteenth century, large numbers of "koelies" were sent from different districts to Colombo and

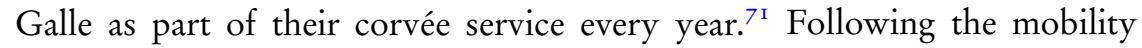
involved in corvée duties and in response to corvée workers avoiding their duties by "roaming around the country", the Company issued regulations proclaiming that "all chitties, Moors or paruas, without distinction and nobody excluded, are obliged to carry a pass signed by the supervisor of their residency", and that they "were obliged to be able to provide this pass to anyone legitimated to ask for it". These passes indicated the place and the number under which the person was administrated on the oeliammersrolle (the corvée duty roll), ensuring the effectiveness of the corvée labour system. ${ }^{72}$

\section{CONCLUSIONS}

The impact of early globalization went well beyond that of market integration or cultural exchange. The case of the VOC provides a clear picture of the drastic effects of labour mobilization on the production and transport of the global commodities involved. Systems of coerced labour were at the core of the Dutch East India Company empire. The VOC interfered in the production of its main trading commodities in different, but at times farreaching, ways, nurturing more or less directly systems of slave and corvée labour for the production of cloves, mace, nutmeg, cinnamon, and coffee, and playing more indirect roles in coercive labour relations in the production of sugar and pepper. Coercive labour regimes were not restricted to

69. Wagenaar, Galle, pp. I66-17г.

70. See the reports of overseers and engineers in SLNA $1 / 3164$.

7I. SLNA I/ 443 .

72. Hovy, Ceylonees Plakkaatboek, p. 324. Original: "dat na deezen all chittys, Mooren of paruassen, zonder onderscheyt en niemand uytgezondert, gehouden [zullen zyn] een briefje door den gebieder harer woonplaats selfs voor de eerste maal en vervolgens (dat verjaard zijnde) door iemand anders onderteekent [bij zich] te dragen, en telkens als haar dat gevergt word door degene die daartoe gewettigt zijn te vertoonen, waarbij zal blijken moeten dat zij [weezent]lijk op de oeliammersrolle aldaar en onder wat nommer zij op dezelve bekent staan". 
agricultural production sites. Slaves were employed on board small vessels transporting cargo between port and ships, or hinterland and port, in Batavia as well as Galle. These slaves were either owned or hired by the Company or merchants loading its ships. Just as important were the corvée labour systems that were appropriated and intensified by the Dutch in different parts of the Dutch-Asian empire. This type of bonded labour, which is often associated with local systems of agricultural production, was just as easily redirected by the VOC for transportation and port work (Ceylon, Java).

Port work was typically the place where labour regimes employed on land and at sea collided and/or functioned alongside each other. Indeed, throughout the early modern period, much of the work "on water" was done by the sailors of the oceangoing ships that were loaded and unloaded. Other groups of local workers, however, seem to have been crucial in all parts of the processes involved, both for the work on land as well as on the water, right up to the transferring of goods onto the oceangoing ships. The labour relations under which these local workers were employed often reflected the practices in use locally, which were strongly shaped by larger processes of imperial expansion.

Ports especially were places were sailors - mainly working on long-term, strict labour contracts - could be employed alongside casual wage workers as well as coerced workers. Systems of labour exploitation on the waterfronts of the Dutch early modern empire were extremely flexible. Casual wage labour was used for port work and related transportation in economic (and imperial) cores, as well as peripheries. Although urban and more rural markets for casual wage labour were widespread (Batavia; north-east Java), coerced labour was crucial also in urban contexts, partly undermining workers' bargaining position. In Batavia, Chinese casual wage labourers were replaced (to some extent successfully) with Indian sailors (contract workers), European sailors, and Asian slaves. On the north-east coast of Java, intensifying systems of corvée labour were preferred to the use of casual wage labour.

This global history of production and transportation furthermore indicates that the waterfronts and hinterlands of the ports of the early modern Dutch Empire witnessed a complex interplay between systems of organizing work through labour contracts, casual wage labour markets, enslavement, and corvée labour obligations. Sailors employed on contract labour were employed everywhere - most of them worked on the ships being loaded or unloaded; in some cases, these sailors were not employed onboard ships, but solely for port work. In addition to (specialized, contracted) sailors, large numbers of other, local workers were employed in the loading and unloading of ships and the related transportation work on land and water. Among this large body of workers, coercive labour relations were at the core. Corvée, slave, and (in some cases) casual wage labour were employed alongside each other. 
This overview of labour relations in the production and transport stages of the commodity chains of key global commodities of the VOC gives us a picture of a so-called "trading company" that operated more as a coercive state and creative agriculturalist than as a joint-stock merchant enterprise. The Dutch East India Company was an amphibious monster that not only worked from sea to land, but increasingly worked from land to sea. The results hint, firstly, at the need to rethink existing notions of the making of the modern world, the development of capitalism, of "free" labour markets, and of wage labour. It indicates the importance of further scrutinizing how coercive and casual labour systems existed or functioned in "clusters" alongside and in relation to each other - and how these transformed not linearly and singularly but transitioned from one specific constellation of clusters of labour relations to another. And, secondly, it seems to stress the importance of further questioning early modern global changes with an open understanding of the concepts of imperialism and capitalism, and with new interest in the early transformations set in motion by merchant capital not only on the imperial maritime frontiers, but also in the South and South East Asian and wider global countryside. 